\title{
Association of Dental Caries with HLA Class II Allele in Brazilian Adolescents
}

\author{
N. Valarini ${ }^{a}$ S.M. Maciel ${ }^{a, b}$ S.K. Moura ${ }^{a}$ R.C. Poli-Frederico ${ }^{c}$ \\ ${ }^{a}$ North Paraná University (UNOPAR), Londrina, ${ }^{b}$ Dental School, Maringa State University (UEM), Maringá, and \\ 'Dental School, North Paraná University (UNOPAR), Londrina, Brazil
}

\author{
Key Words \\ Adolescent $\cdot$ Dental caries $\cdot$ Genetic polymorphism $\cdot$ HLA \\ antigens
}

\begin{abstract}
The purpose of this study was to evaluate the association between the frequencies of DR and DQ HLA class II alleles and the prevalence of dental caries in Brazilian adolescents. The study sample consisted of 164 adolescents aged 1519 years. For the assessment of caries experience the DMFT index was used, according to World Health Organization criteria. DNA samples of the adolescents were extracted from oral mucosa cells. The amplification of the alleles HLA-DR and HLA-DQ was carried out by polymerase chain reaction with sequence-specific primers (PCR-SSP). The products of PCR-SSP were electrophoresed and analyzed in agarose gel. Statistical analysis was performed using simple and multiple logistic regression to test the association between the adolescents' caries experience and the presence of HLA-DR and -DQ alleles. Sociodemographic covariates were included in the model. The significance level for all analyses was $p<0.05$. The prevalence of caries was $60.4 \%$ and the mean DMFT was $2.41 \pm 2.53$. Adolescents positive for HLA-DQ2 allele were less likely to have dental caries than their counterparts who were negative for this allele ( $\mathrm{OR}=0.33, \mathrm{Cl} 0.16-0.66)$, and those whose mothers presented low levels of education were 2.01 ( $\mathrm{Cl}$ 1.02-3.97) times more likely to have dental caries. There was no statistical difference between HLA-DR4,
\end{abstract}

-DQ4, -DQ5, -DQ6 and dental caries. Our data provide evidence that genes within the MHC, especially the DQ2 group, may influence susceptibility to dental caries in Brazilian adolescents.

Copyright $\odot 2012$ S. Karger AG, Basel

Despite the general decline in caries disease, it is still a significant problem in many countries [Petersen et al., 2005]. It has also a considerable impact on individuals and communities, since it causes pain, suffering, impairment of function and reduced quality of life [World Health Organization, 2003]. Moreover, traditional treatment of caries is extremely costly, representing the fourth most expensive disease to treat in most of the industrialized world, and the access to appropriate treatment is difficult in many low-income countries [Yee and Sheiham, 2002].

Dental caries is a chronic, complex and multifactorial disease. It results from the interaction between the host, the host's diet, and the microflora on the tooth surface bounded by the time factor [Newbrun, 1989]. Although widely known as a disease mostly influenced by environmental factors, there is also increased evidence for a genetic component in caries susceptibility [Werneck et al., 2010; Kang et al., 2011; Wang et al., 2012]. According to Vieira et al. [2008], the factors related to the host may be influenced by genetic components, but environmental factors may overcome the individual's genetic susceptibility to the disease. Socioeconomic conditions, besides

\section{KARGER}

Fax +41613061234

E-Mail karger@karger.ch

www.karger.com
(C) 2012 S. Karger AG, Basel

$0008-6568 / 12 / 0466-0530 \$ 38.00 / 0$

Accessible online at:

www.karger.com/cre
Regina Célia Poli-Frederico

Faculty of Dentistry, University of Northern Parana (UNOPAR)

Rua Marselha 183, Jardim Piza

Londrina, PR, CEP 86041-120 (Brazil)

Tel. +55 433371 7820, E-Mail regina.frederico@ unopar.br 
the biologic factors, may interfere in dental caries prevalence, which affects more extensively and more seriously disadvantaged groups, disclosing a scenario of inequity in the distribution of the disease [Narvai et al., 2006].

Alterations in the immune response to cariogenic bacteria may also be related to dental caries [Yildiz et al., 2009]. Some studies report that there is a relationship between HLA types and an increased incidence of caries [Acton et al., 1999]. The term HLA refers to the human leukocyte antigen system and it is a collection of genes arranged within a long, continuous stretch of DNA on chromosome 6p21.3. The HLA loci are part of the genetic region known as the major histocompatibility complex, which encodes polymorphic class I, II and III molecules that play a major role in antigen processing and presentation to the T-cell receptor, which is crucial for the cell interactions in cell-mediated immunity [Altun et al., 2008]. Therefore, differences in HLA molecules can cause variations in the immune response to microorganisms, such as Streptococcus mutans, and may influence the individual's susceptibility to dental caries [Bagherian et al., 2008]. HLA-DR and -DQ gene polymorphism, which results in different amino acid residues, will affect not only the recognition of the peptide by the T-cell receptor but also the interaction between the T-cell receptor and HLA molecules. Furthermore, different HLA alleles may encode HLA molecules with differing affinity for bacterial peptides [Ozawa et al., 2001].

Associations between dental caries and the HLA region were obtained in both animal [Niiyama et al., 1987; Kurihara et al., 1991; Suzuki et al., 1998] and human studies [Lehner et al., 1981; Acton et al., 1999; Altun et al., 2008; Bagherian et al., 2008; Yildiz et al., 2009]. In the study conducted by Lehner et al. [1981] the genetic predisposition towards caries was found to be positively associated with HLA-DR4 antigens and negatively with HLA-DRw6-related antigens. However, de Vries et al. [1985] did not replicate these findings in a similar study, in which there was no association between HLA-DR types and caries experience. Recent studies have shown a relationship between HLA and increased risk for dental caries and higher levels of cariogenic bacteria in individuals [Acton et al., 1999; Altun et al., 2008; Yildiz et al., 2009]. Bagherian et al. [2008] recommended HLA$\mathrm{DRB}^{*} 04$ detection as a molecular marker for early diagnosis of early childhood caries.

The aim of this study was to evaluate the association between allelic frequencies for HLA-DR4, -DQ2, -DQ4, -DQ5 and -DQ6 and the experience of dental caries in Brazilian adolescents.

\section{Subjects and Methods}

\section{Study Subjects}

For this cross-sectional study, all students who were attending the 2nd year of high school classes from a public school located in the central area in the city of Londrina, Parana, Brazil, were initially eligible $(n=192)$. This school was chosen because it presented a greater number of students attending high school. All of the students were invited to participate in the study and the inclusion criterion was age-related and students should be between 15 and 19 years of age, while the exclusion criterion was met if written informed consent was not signed by legal guardians. A total of 164 adolescents participated in the research (positive response rate of $85.2 \%)$.

The aim and details of the experiments were explained, and informed consent forms were obtained from parents or legal guardians of the adolescents prior to the beginning of the experimental procedures. The research was approved by the Ethics Committee of the University of North of Parana and by the local health and education authorities.

Demographic and social characteristics were obtained through personal interviews with the adolescents using a semistructured questionnaire previously tested in the pilot study. The demographic variables were the adolescent's age (15, 16, 17-19 years), gender (male, female) and skin color/race (white and nonwhite). The social characteristics studied were maternal educational level in years of study ( $\leq 8$ years and $>8$ years) and monthly family income calculated in Brazilian currency - Reais ( $\leq$ BRL 1,245.00, BRL 1,246.00-2,075.00, $\geq$ BRL 2,076.00).

The prevalence of dental caries was determined by the DMFT index (number of decayed, missing, and filled permanent teeth), according to the criteria defined by the World Health Organization [World Health Organization, 1997]. To analyze the relationship between the experience of caries and the independent variables, the DMFT was dichotomized into DMFT $=0$ (adolescents without caries experience) and DMFT $\geq 1$ (adolescents with caries experience).

The clinical examination was performed in school settings, by the same examiner, under indirect natural illumination, using clinical mirrors and CPI probes, with both the examiner and the patient seated. Prior to examination, the teeth were cleaned with gauze. Revised infection control guidelines were followed to protect the research team and patients. The data were written down by trained recorders in individualized patient forms.

Intraexaminer agreement for caries was considered excellent, with a kappa statistic of 0.97 .

\section{DNA Extraction}

Genomic DNA was obtained from epithelial cells from epithelial buccal cells as previously described [Aidar and Line, 2007]. The subjects were asked to vigorously rinse their mouths with a 5 -ml solution of sucrose (3\%) for $60 \mathrm{~s}$, and each individual mouthwash was collected in a 15-ml centrifuge tube. In each tube, $3 \mathrm{ml}$ of TNE solution (17 mM Tris- $\mathrm{HCl}, \mathrm{pH} 8.0 ; 50 \mathrm{mM} \mathrm{NaCl} ; 7 \mathrm{mM}$ EDTA) was diluted in $66 \%$ ethanol. The epithelial buccal cells were centrifuged for $10 \mathrm{~min}$ at 3,000 rpm and resuspended in $1 \mathrm{ml}$ of a solution containing $10 \mathrm{~mm}$ Tris ( $\mathrm{pH} 8.0$ ), 0.5\% SDS, $5 \mathrm{~mm}$ EDTA and proteinase $\mathrm{K}(20 \mathrm{mg} / \mathrm{ml})$, followed by an overnight incubation at $55^{\circ} \mathrm{C}$. After incubation, proteins and other contaminants were removed by adding a solution containing $8 \mathrm{M}$ ammo- 
Table 1. Oligonucleotide primers used in the PCR-SSP for HLA-DR and HLA-DQ allelic typing $(\mathrm{n}=164)$

\begin{tabular}{|c|c|c|c|}
\hline Allele & Genotype & Sequence $\left(5^{\prime}\right.$ to $\left.3^{\prime}\right)$ & Amplicon size, bp \\
\hline HLA-DQ2 & 0201 & $\begin{array}{l}\text { GTG-CGT-CTT-GTG-AGC-AGA-AG } \\
\text { TGC-AAG-GTC-GTG-CGG-AGC-T }\end{array}$ & 206 \\
\hline HLA-DQ4 & 0401-0402 & $\begin{array}{l}\text { GTG-CTA-CTT-CAC-CAA-CGG-GAC-C } \\
\text { CTG-GTA-GTT-GTG-TCT-GCA-TAC-G }\end{array}$ & 211 \\
\hline HLA-DQ5 & 0501-0504 & $\begin{array}{l}\text { GAC-GGA-GCG-CGT-CCG-GGG } \\
\text { TGC-AGG-ATC-CCG-CGG-TAC-G } \\
\text { GGG-ACG-GAG-CGC-GTG-CGT-TA }\end{array}$ & 216 \\
\hline HLA-DQ6 & 0601-0609 & $\begin{array}{l}\text { GGG-ACG-GAG-CGC-GTG-CGT-CT } \\
\text { CTG-CAA-GAT-CCC-GCG-GAA-CG } \\
\text { TGC-AGG-ATC-CCG-CGG-TAC-C }\end{array}$ & $218-219$ \\
\hline HLA-DR4 & DR4 & $\begin{array}{l}\text { CGT-TTC-TTG-GAG-CAG-GTT-AAA-CA } \\
\text { CTC-GCC-GCT-GCA-CTG-TG }\end{array}$ & 213 \\
\hline HGHg & HGHg & $\begin{array}{l}\text { GCC-TTC-CCA-ACC-ATT-CCC-TTA } \\
\text { TCA-CGG-ATT-TCT-GTT-GTG-TTT-C }\end{array}$ & 360 \\
\hline
\end{tabular}

nium acetate and $1 \mathrm{~mm}$ EDTA, followed by vortexing at high speed for $5 \mathrm{~s}$ and centrifuging at $17,000 \mathrm{~g}$ for $10 \mathrm{~min}$. The DNA pellet was washed with ethanol and resuspended in a TE solution (10 mM Tris, pH 7.8; $1 \mathrm{~mm}$ EDTA). DNA then was conditioned at $-4^{\circ} \mathrm{C}$, prior to the PCR analysis.

Genetic Polymorphism Analysis by PCR-SSP

The presence of HLA-DR4, -DQ2, -DQ4, -DQ5 and -DQ6 alleles was determined by polymerase chain reaction amplification of genomic DNA with sequence-specific primers (PCR-SSP). For DNA amplification, the primer sequences, PCR reaction profiles and expected product sizes for the DR and DQ alleles have previously been reported by Olerup and Zetterquist [1992] and Aldener-Cannavá and Olerup [1994], respectively (table 1). To check the PCR conditions, the internal positive control primer pairs that amplify the human growth hormone gene (HGHg) segments were used, and as a negative control, ultrapure water was used.

The PCR master mix for DR4 alleles contained $1 \times$ buffer, $1.5 \mathrm{mM} \mathrm{MgCl}_{2}, 200 \mu \mathrm{M}$ dNTP, $1 \mu \mathrm{M}$ HLA-DRB1*04, $0.2 \mu \mathrm{M}$ $\mathrm{HGHg}$ and $1 \mathrm{U}$ Taq DNA polymerase (Invitrogen Life Technologies $^{\circledR}$, São Paulo, Brazil). PCR amplifications were carried out in a thermal cycler (Endurance TC-512 Techne ${ }^{\mathrm{TM}}$, Burlington, N.J., USA). After an initial denaturation at $94^{\circ} \mathrm{C}$ for $5 \mathrm{~min}$, a total of 30 PCR cycles were performed; each cycle consisted of denaturation at $94^{\circ} \mathrm{C}$ for $20 \mathrm{~s}$, annealing at $50^{\circ} \mathrm{C}$ for $50 \mathrm{~s}$, extension at $72^{\circ} \mathrm{C}$ for $20 \mathrm{~s}$ and a final extension for $5 \mathrm{~min}$ at $72^{\circ} \mathrm{C}$.

For the DQ2, DQ4, DQ5 and DQ6 alleles, the PCR master mix contained $1 \times$ buffer, $1.5 \mu \mathrm{M} \mathrm{MgCl}_{2}, 200 \mu \mathrm{M}$ dNTP, $0.4 \mu \mathrm{M}$ HLA$\mathrm{DRB1}^{*} 02,04,05$ and $06,0.1 \mu \mathrm{M} \mathrm{HGHg}$, and $1 \mathrm{U}$ Taq DNA polymerase (Invitrogen Life Technologies). After an initial denaturation at $94^{\circ} \mathrm{C}$ for $2 \mathrm{~min}$ the DNAs were amplified by 30 amplification cycles. The first 10 cycles consisted of denaturation at $94^{\circ} \mathrm{C}$ for $10 \mathrm{~s}$ and a combined annealing-extension step at $65^{\circ} \mathrm{C}$ for $60 \mathrm{~s}$. The 20 following cycles consisted of denaturation at $94^{\circ} \mathrm{C}$ for $10 \mathrm{~s}$, annealing at $61^{\circ} \mathrm{C}$ for $50 \mathrm{~s}$ and extension at $72^{\circ} \mathrm{C}$ for $30 \mathrm{~s}$.
Visualization of Amplifications by Agarose Gel

Electrophoresis

Following amplification, the products of PCR-SSP were electrophoresed on a $2 \%$ agarose gel. A 100-bp DNA ladder was included on each gel. The agarose gel was stained with $5 \mu$ l of Sybr Safe (Invitrogen Life Technologies) and visualized under UV illumination. The reading and interpretation of the agarose gels were made with the LabImage L-PIX (H.E.) 1D-L340 program (Loccus Biotecnologia, Brazil).

\section{Statistical Analysis}

Data were analyzed using the Statistical Package for Social Sciences. Simple and multiple logistic regression analyses were used to test the association between the adolescents' caries experience and the presence of HLA-DR4, -DQ2, -DQ4, -DQ5 and -DQ6 alleles. Sociodemographic covariates were included in the unadjusted model. The significance level for all analyses was $p<0.05 ; \chi^{2}$ tests determined Hardy-Weinberg equilibrium for DR and DQ HLA class II alleles to compare the observed allelic frequency with those expected under Hardy-Weinberg equilibrium. Linkage disequilibrium (LD) was determined between all alleles using ARLEQUIN 3.1 [Excoffier et al., 2007].

\section{Results}

Among the adolescents there was a predominance of females $(69.5 \%)$, white skin color/race $(68.9 \%)$, age of 15 years $(45.7 \%)$, and mothers with low levels of education (53.0\%, table 2$)$. The mean monthly family income was about BRL 1,583.27. 


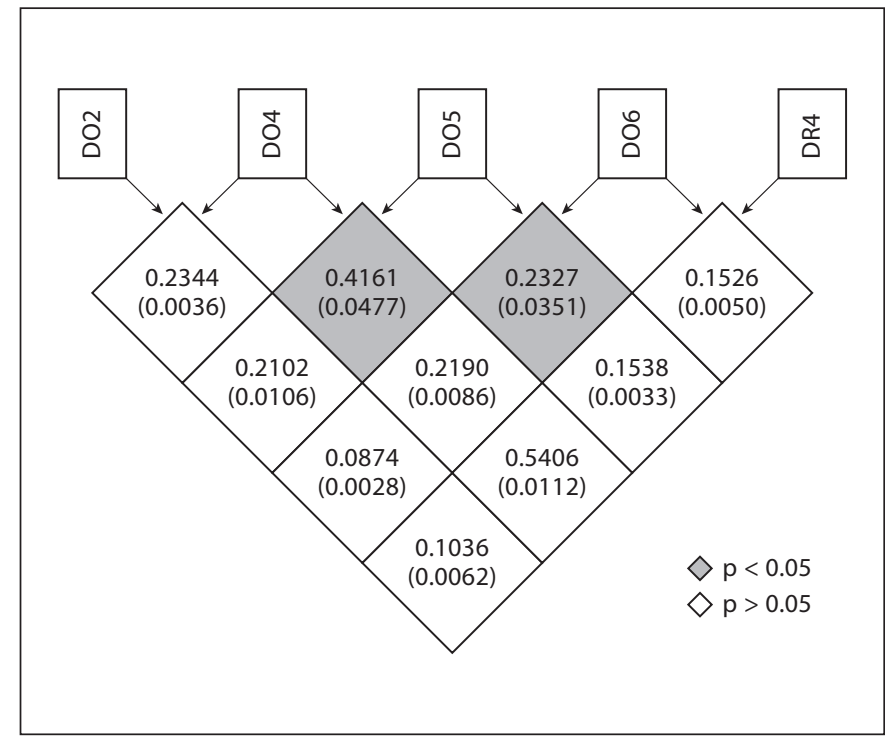

Fig. 1. Schematic representation of LD between the five HLA alleles that were analyzed. D' for LD between each marker is reported; $r^{2}$ values between markers are reported in parentheses.

Dental caries prevalence was high. Only $39.6 \%$ of the adolescents studied were caries-free (table 2). The mean DMFT was $2.41 \pm 2.53$.

The results of genetic polymorphism analysis regarding the presence of HLA class II alleles in the adolescents showed a higher frequency of DQ6 allele (45.1\%), followed by DQ5 (34.8\%), DQ2 (31.1\%), DR4 (20.1\%) and DQ4 (12.8\%) alleles (table 3). All the alleles tested were in Hardy-Weinberg equilibrium. None of the alleles were in perfect linkage disequilibrium. Significant LD was found only between DQ5/DQ4 and DQ5/DQ6 alleles (fig. 1).

Results from simple logistic regression (table 4) showed that the presence of HLA-DQ2 allele was associated with the adolescents' caries experience. Adolescents positive for this allele were less likely to experience dental caries than those who were negative $(\mathrm{p}=0.003)$. Maternal educational level was also significantly associated with the outcome variable $(p=0.042)$. None of the other variables were significant.

In the multiple logistic regression (table 5), the presence of HLA-DQ2 allele $(\mathrm{p}=0.002)$ and the maternal level of education $(p=0.043)$ remained significant, indicating that both these variables were independently related to the adolescents' caries experience. Adolescents positive for HLA-DQ2 allele were less likely to have dental caries than their counterparts, who were negative for
Table 2. Characterization of the adolescents according to sociodemographic and caries experience $(n=164)$

\begin{tabular}{lrl}
\hline Characteristics & $\mathrm{n}$ & $\%$ \\
\hline Adolescent gender & & \\
$\quad$ Male & 50 & 30.5 \\
$\quad$ Female & 114 & 69.5 \\
Adolescent age & & \\
$\quad$ 15 years & 75 & 45.7 \\
$\quad 16$ years & 48 & 29.3 \\
$\quad$ 17-19 years & 41 & 25.0 \\
Skin color/race & 113 & \\
$\quad$ White & 51 & 68.9 \\
$\quad$ Nonwhite & & 31.1 \\
Maternal educational level & 87 & 53.0 \\
$\quad \leq 8$ years & 77 & 47.0 \\
$\quad>8$ years & & \\
Family income, BRL & 61 & 37.2 \\
$\quad \leq 1,245.00$ & 39 & 23.8 \\
$\quad 1,246.00-2,075.00$ & 64 & 39.0 \\
$\quad \geq 2,076.00$ & & \\
Dental caries experience & 99 & 60.4 \\
$\quad$ With caries & 65 & 39.6 \\
$\quad$ Without caries & & \\
\hline
\end{tabular}

Table 3. Frequency of the HLA-DR4 and HLA-DQ2, -DQ4, -DQ5 and -DQ6 alleles in adolescents $(n=164)$

\begin{tabular}{lll}
\hline Allele & $\mathrm{n}$ & $\%$ \\
\hline HLA-DR4 & 33 & 20.1 \\
HLA-DQ2 & 51 & 31.1 \\
HLA-DQ4 & 21 & 12.8 \\
HLA-DQ5 & 57 & 34.8 \\
HLA-DQ6 & 74 & 45.1 \\
\hline
\end{tabular}

this allele, the odds ratio being 0.33 (CI 0.16-0.66). In addition, adolescents whose mothers presented low levels of education were 2.01 times more likely to have dental caries.

\section{Discussion}

Although caries formation depends on many other factors in addition to levels of cariogenic organisms and immune responsiveness, such as tooth anatomy, diet, and overall health [Caufield, 1997], this study's main purpose was to investigate a possible association between HLADR and HLA-DQ alleles and dental caries. 
Table 4. Simple logistic regression of exploratory variables on the caries experience of Brazilian adolescents $(n=164)$

\begin{tabular}{|c|c|c|c|}
\hline $\begin{array}{l}\text { Exploratory } \\
\text { variables }\end{array}$ & $\begin{array}{l}\text { With caries } \\
\mathrm{n}(\%)\end{array}$ & $\begin{array}{l}\text { Unadjusted } \\
\text { OR }(95 \% \mathrm{CI})\end{array}$ & $\begin{array}{l}\mathrm{p} \\
\text { values }\end{array}$ \\
\hline \multicolumn{4}{|l|}{ Adolescent gender } \\
\hline Female & $67(58.8)$ & 1 & \\
\hline Male & $32(64.0)$ & $0.80(0.40-1.59)$ & 0.529 \\
\hline \multicolumn{4}{|l|}{ Adolescent age } \\
\hline 15 years & $44(58.7)$ & 1 & \\
\hline 16 years & $30(62.5)$ & $1.17(0.56-2.47)$ & 0.672 \\
\hline 17-19 years & $25(61.0)$ & $1.10(0.51-2.40)$ & 0.808 \\
\hline \multicolumn{4}{|l|}{ Skin color/race } \\
\hline White & $66(58.4)$ & 1 & \\
\hline Nonwhite/race & $33(64.7)$ & $1.30(0.66-2.59)$ & 0.396 \\
\hline \multicolumn{4}{|c|}{ Maternal educational level } \\
\hline$>8$ years & $40(51.9)$ & 1 & \\
\hline$\leq 8$ years & $59(67.8)$ & $1.95(1.03-3.67)$ & 0.042 \\
\hline \multicolumn{4}{|c|}{ Family income, BRL } \\
\hline$\geq 2,076.00$ & $38(59.4)$ & 1 & \\
\hline $1,246.00-2,075.00$ & $24(61.5)$ & $1.09(0.45-2.47)$ & 0.835 \\
\hline$\leq 1,245.00$ & $37(60.7)$ & $1.05(0.51-2.16)$ & 0.881 \\
\hline \multicolumn{4}{|l|}{ HLA-DR4 allele } \\
\hline Absence & $78(59.5)$ & 1 & \\
\hline Presence & $21(63.6)$ & $1.19(0.53-2.62)$ & 0.665 \\
\hline \multicolumn{4}{|l|}{ HLA-DQ2 allele } \\
\hline Absence & $77(68.1)$ & 1 & \\
\hline Presence & $22(43.1)$ & $0.35(0.18-0.70)$ & 0.003 \\
\hline \multicolumn{4}{|l|}{ HLA-DQ4 allele } \\
\hline Absence & $86(60.1)$ & 1 & \\
\hline Presence & 13 (61.9) & $1.07(0.42-2.76)$ & 0.877 \\
\hline \multicolumn{4}{|l|}{ HLA-DQ5 allele } \\
\hline Absence & $64(59.8)$ & 1 & \\
\hline Presence & $35(61.4)$ & $1.07(0.55-2.06)$ & 0.843 \\
\hline \multicolumn{4}{|l|}{ HLA-DQ6 allele } \\
\hline Absence & $54(60.0)$ & 1 & \\
\hline Presence & $45(60.8)$ & $1.03(0.55-1.94)$ & 0.916 \\
\hline
\end{tabular}

We did not observe an association between HLADQ4, -DQ5, -DQ6 and -DR4 alleles with the experience of dental caries. This finding is in line with previous studies that failed to observe an association between dental caries and HLA-DRB1 alleles [de Vries et al., 1985; Acton et al., 1999; Altun et al., 2008].

It must be kept in mind that findings tend to be affected by the methodology used. Thus, comparison with other studies is difficult. The study reported by Lehner et al. [1981] suggested a DR4 caries connection. However, it did not provide high resolution genotyping as the antigens tested were determined by immunological reactions and not direct DNA sequencing.

Bagherian et al. [2008] also reported that the DR4positive subjects younger than 5 years were 10 times more
Table 5. Multiple logistic regression of exploratory variables on the caries experience of Brazilian adolescents $(n=164)$

\begin{tabular}{lll}
\hline Exploratory variables & $\begin{array}{l}\text { Adjusted } \\
\text { OR }(95 \% \mathrm{CI})\end{array}$ & $\begin{array}{l}\mathrm{p} \\
\text { values }\end{array}$ \\
\hline $\begin{array}{l}\text { Maternal educational level } \\
\quad>8 \text { years } \\
\quad \leq 8 \text { years }\end{array}$ & 1 & \\
$\begin{array}{l}\text { HLA-DQ2 allele } \\
\text { Absence } \\
\text { Presence }\end{array}$ & $2.01(1.02-3.97)$ & 0.043 \\
\hline
\end{tabular}

likely to develop early childhood caries than their negative counterparts. In the same way, Yildiz et al. [2009] found that HLA-DRB1*04 and $-\mathrm{DRB1}^{*} 07$ frequencies were significantly higher in the DMFT $\geq 1$ group as compared with the DMFT $=0$ group.

Surprisingly the results of this study revealed an association between dental caries and a different allele, specifically HLA-DQ2. Adolescents positive for HLA-DQ2 allele were less likely to have dental caries. We hypothesize that ethnic differences might explain the difference, the immunological genetic repertoire being selected over time as a consequence of exposure to infectious agents [Acton et al., 1999]. One set of authors recently observed that identical diseases might be associated with different HLA-II alleles in different ethnic groups or populations [Bondinas et al., 2007]. Moreover, it is known that many genes that code for molecules involved in the immune response are polymorphic [Yildiz et al., 2009]. Thus, further studies are needed to elucidate the nature of this relationship.

Although the study's main purpose was to investigate a possible relationship between HLA alleles and dental caries, its results confirm the well-known relationship between dental caries and maternal level of education. Adolescents whose mothers had the lowest levels of education were 2.01 times more likely to experience dental caries. These findings are consistent with those described by Nadanovsky and Sheiham [1995], Freire et al. [2001] and Moreira et al. [2006]. Interestingly, the latter noted that the level of maternal education was the only sociodemographic variable that showed significant association with the presence or absence of dental caries, similar to our findings.

Our data provide evidence that having genes within the major histocompatibility complex, specially the DQ2 group, may be one of the factors that influence suscepti- 
bility to dental caries in Brazilian adolescents. Considering that little is known about the genetic basis of HLA for dental caries in the Brazilian population, the analysis of genetic polymorphism in a sample from this population represents important information concerning dental caries in Brazil.

\section{Acknowledgments}

The authors would like to thank the FUNADESP and UNOPAR (PP/0213/10) for financial support.

\section{Disclosure Statement}

The authors have no conflict of interest to declare.

\section{References}

-Acton RT, Dasanayake AP, Harrison RA, Li Y, Freire MC, Sheiham A, Hardy R: Adolescents' Roseman JM, Go RC, Wiener H, Caufield PW: Associations of MHC genes with levels of caries-inducing organisms and caries severity in African-American women. Hum Immunol 1999;60:984-989.

- Aidar M, Line SR: A simple and cost-effective protocol for DNA isolation from buccal epithelial cells. Braz Dent J 2007;18:148-152.

-Aldener-Cannavá A, Olerup O: HLA-DQB1 low resolution typing by PCR amplification with sequence-specific primers (PCR-SSP). Eur J Immunogenet 1994;21:447-455.

-Altun C, Guven G, Orkonoglu F, Cehreli ZC, Karaaslan A, Basak F, Akbulut E: Human leukocyte antigen class II alleles and dental caries in a child population. Pediatr Dent 2008;30:154-159.

-Bagherian A, Nematollahi H, Afshari JT, Moheghi N: Comparison of allele frequency for HLA-DR and HLA-DQ between patients with ECC and caries-free children. J Indian Soc Pedod Prev Dent 2008;26:18-21.

-Bondinas GP, Moustakas AK, Papadopoulos GK: The spectrum of HLA-DQ and HLA-DR alleles, 2006: a listing correlating sequence and structure with function. Immunogenetics 2007;59:539-553.

-Caufield PW: Dental caries - a transmissible and infectious disease revisited: a position paper. Pediatr Dent 1997;19:491-498.

de Vries RR, Zeylemaker P, van Palenstein Helderman WH, Huis in't Veld JH: Lack of association between HLA-DR antigens and dental caries. Tissue Antigens 1985;25:173174.

-Excoffier L, Laval G, Schneider S: Arlequin (version 3.0): an integrated software package for population genetics data analysis. Evol Bioinform Online 2007;1:47-50. sense of coherence, oral health status, and oral health-related behaviours. Community Dent Oral Epidemiol 2001;29:204-212.

Kang SW, Yoon I, Lee HW, Cho J: Association between AMELX polymorphism and dental caries in Koreans. Oral Dis 2011;17:399-406.

-Kurihara Y, Naito T, Obayashi K, Hirasawa M, Kurihara Y, Moriwaki K: Caries susceptibility in inbred mouse strains and inheritance patterns in F1 and backcross (N2) progeny from strains with high and low caries susceptibility. Caries Res 1991;25:341-346.

Lehner T, Lamb JR, Welsh KL, Batchelor RJ: Association between HLA-DR antigens and helper cell activity in the control of dental caries. Nature 1981;292:770-772.

- Moreira PV, Rosenblatt A, Severo AM: Prevalence of dental caries in obese and normal weight Brazilian adolescents attending state and private schools. Community Dent Health 2006;23:251-253.

-Nadanovsky P, Sheiham A: Relative contribution of dental services to the changes in caries levels of 12 -year-old children in 18 industrialized countries in the 1970s and early 1980s. Community Dent Oral Epidemiol 1995;23: 331-339.

-Narvai PC, Frazão P, Roncalli AG, Antunes JLF: Cárie dentária no Brasil: declínio, iniqüidade e exclusão social. Rev Panam Salud Publica 2006;19:385-393.

Newbrun E: Effectiveness of water fluoridation. J Public Health Dent 1989;49:279-289.

Niiyama T, Kojima H, Mizuno K, Matsuno Y, Fujii H, Misonou J, Natori T, Aizawa M, Oikawa $\mathrm{K}$ : Genetic control of the immune responsiveness to Streptococcus mutans by the major histocompatibility complex of the rat (RT1). Infect Immun 1987;55:3137-3141.

-Olerup O, Zetterquist H: HLA-DR typing by PCR amplification with sequence-specific primers (PCR-SSCP) in 2 hours: an alternative to serological DR typing in clinical practice including donor-recipient matching in cadaveric transplantation. Tissue Antigens 1992;39:225-235.
Ozawa Y, Chiba J, Sakamoto S: HLA class II alleles and salivary numbers of mutans streptococci and lactobacilli among young adults in Japan. Oral Microbiol Immunol 2001;16: 353-357.

- Petersen PE, Bourgeois D, Ogawa H, EstupinanDay S, Ndiaye C: The global burden of oral diseases and risks to oral health. Bull World Health Organ 2005;83:661-669.

Suzuki N, Kurihara Y, Kurihara Y: Dental caries susceptibility in mice is closely linked to the $\mathrm{H}-2$ region on chromosome 17. Caries Res 1998;32:262-265.

-Vieira AR, Marazita ML, Goldstein-McHenry T: Genome-wide scan finds suggestive caries loci. J Dent Res 2008;87:435-439.

-Wang X, Willing MC, Marazita ML, Wendell S, Warren JJ, Broffitt B, Smith B, Busch T, Lidral AC, Levy SM: Genetic and environmental factors associated with dental caries in children: the Iowa Fluoride Study. Caries Res 2012;46:177-184.

Werneck RI, Mira MT, Trevilatto PC: A critical review: an overview of genetic influence on dental caries. Oral Dis 2010;16:613-623.

World Health Organization: Oral Health Surveys - Basic Methods, ed 4. Geneva, World Health Organization, 1997.

World Health Organization: The World Oral Health Report 2003. Geneva, World Health Organization, 2003.

-Yee R, Sheiham A: The burden of restorative dental treatment for children in third world countries. Int Dent J 2002;52:1-9.

Yildiz M, Pirim I, Bayindir YZ, Olgun H, Temel F: The association of HLA class I and II antigens in teenagers with caries experience. Eurasian J Med 2009;41:146-148. 